\title{
TEXT AND DISCOURSE IN A SEMIOTIC RELATIONSHIP
}

\author{
Evgeniy F. Kirov
}

Pushkin State Russian Language Institute, Moscow, Russia

\begin{abstract}
The text and discourse are very closely related to each other, the text can be perceived as a sign of discourse in semiotic terms. This means that the text turns into a discourse in the semiosis, i.e. a symbolic situation where the addressee understands (at least minimally) the information in the text as a result of reading or listening and is exposed to a pragmatic effect.

From this it can be concluded that any text is a potential discourse, and discourse is an updated text with the addressee (or addressees), who understood the content of discourse interaction, functioning as a means of achieving certain goals. As soon as the text is being to be perceived by the addressee at the time of reading, it turns into a discourse that transforms the reader or the state of affairs in the world.

The concept of intertextuality entails the concept of mega-text as the totality of all texts on the same topics. In a similar way, we can talk about mega-discourse as the totality of all discourses devoted to one conceptual theme, with mega-discourse consisting of separate discourses recorded in the literature or folklore. The initial calculation of discourses can be started from discourses on one conceptual theme, for example, discourses on love, discourses on happiness, discourses on work, etc. Such discourses can be systematized by taking into account the principle of historicism, that is to start with the first discourse on a certain subject and to continue this line of development and formation of mega-discourse to the latest period, the discourse on the same conceptual theme that has emerged recently.
\end{abstract}

Key words: semiotics, text, discourse, megatext, megadiscourse, speech act, intertextuality, interdiscursivity.

Citation. Kirov E.F. Text and Discourse in a Semiotic Relationship. Vestnik Volgogradskogo gosudarstvennogo universiteta. Seriya 2, Yazykoznanie [Science Journal of Volgograd State University. Linguistics], 2018, vol. 17 , no. 2, pp. 15-25. (in Russian). DOI: https://doi.org/10.15688/jvolsu2.2018.2.2

УДК 81 '22

ББК 81.002
Дата поступления статьи: 03.04.2018

Дата принятия статьи: 07.05.2018

\section{ТЕКСТ И ДИСКУРС В СЕМИОТИЧЕСКОМ СООТНОШЕНИИ}

\author{
Евгений Флорентович Киров \\ Государственный институт русского языка им. А.С. Пушкина, г. Москва, Россия
}

\begin{abstract}
Аннотация. Статья посвящена проблеме взаимосвязи текста и дискурса. Доказано, что текст может восприниматься как знак дискурса в семиотическом плане: текст превращается в дискурс в условиях семиозиса - знаковой ситуации, когда в результате чтения или слушания адресат понимает (хотя бы минимально) информацию в тексте и подвергается прагматическому воздействию.

Показано, что любой текст - это потенциальный дискурс, а дискурс - это актуализированный текст с адресатом (или адресатами), который понял содержание дискурсивной интеракции, функционирующий как $\infty$ средство достижения определенных целей. Как только текст начинает восприниматься адресатом в момент $\underset{\sim}{\vec{\sim}}$ чтения, он превращается в дискурс, преображающий читателя или положение дел в мире.

П По аналогии с взаимосвязанными понятиями интертекстуальности и мегатекста как совокупности всех гі текстов на одну тему автором устанавливается взаимосвязь понятий интердискурсивности и мегадискурса \% как совокупности всех дискурсов на одну концептуальную тему. Установлено, что мегадискурс складывается из отдельных дискурсов, зафиксированных в литературе или фольклоре. Исходное исчисление дискурсов () предложено начинать с дискурсов на одну концептуальную тему (дискурсы о любви, дискурсы о счастье,
\end{abstract}


дискурсы о труде и т. д.), затем систематизировать их с учетом принципа историзма: начинать их исчисление с момента появления первого дискурса и прослеживать линию развития мегадискурса до последнего его элемента, возникшего в последнее время.

Ключевые слова: семиотика, текст, дискурс, мегатекст, мегадискурс, речевой акт, интертекстуальность, интердискурсивность.

Цитирование. Киров Е. Ф. Текст и дискурс в семиотическом соотношении // Вестник Волгоградского государственного университета. Серия 2, Языкознание. - 2018. - T. 17, № 2. - C. 15-25. - DOI: https://doi.org/ 10.15688/jvolsu2.2018.2.2

\section{Введение}

Дискурсу дано много дефиниций [Карасик, 2000; Макаров, 2003; Ревзина, 1999; Серио, 1999 и др.], и это в итоге сделало его предмет расплывчато-определенным, в предельном случае совпадающим с текстом в своей редуцированной дефиниции. Н.Д. Арутюнова понимает дискурс следующим образом: «Дискурс (от франц. discours - речь) - связный текст в совокупности с экстралингвистическими - прагматическими, социокультурными, психологическими и др. факторами; текст, взятый в событийном аспекте; речь, рассматриваемая как целенаправленное социальное действие, как компонент, участвующий во взаимодействии людей и механизмах их сознания (когнитивных процессах). Д. - это речь, “погруженная в жизнь”. Поэтому термин “Д.”, в отличие от термина “текст”, не применяется к древним и др. текстам, связи которых с живой жизнью не восстанавливаются непосредственно» [Арутюнова, 1990, с. 136137]. Мы согласны с таким определением дискурса, однако оговорку о древних текстах мы принять не можем, поскольку вряд ли существует древний текст, который не имеет хотя бы какой-нибудь связи с жизнью в настоящем, то есть не имеет отклика в современных событиях и не является элементом интердискурса как соответствия интертекста (в классическом понимании интертекстуальности Ю. Кристевой, Ж. Деррида и др.).

Очевидная привлекательность идеи итертекстуальности неминуемо должна привести к выделению единицы интертекстуальности, которой мы считаем мегатекст, посвященный одной концептуальной теме. Такие мегатексты в первых своих проявлениях (то есть первых текстах на одну концептуальную тему) возникают в самом начале текстовой деятельности социума, продолжают формироваться в наше время и продолжат развиваться в будущем. Подобно мегатексту, в коммуникативной жизни социума существует мегадискурс как его соответствие. И в этом случае важно охарактеризовать взаимосвязи таких объектов, как дискурс, текст и семиозис.

\section{Текст как знак дискурса}

Не подлежит сомнению, что текст и дискурс тесно связаны друг с другом в семиотическом плане (см., например: [Земская и др., 2010; Серио, 1999]). Текст может пониматься как знак дискурса в семиотической ситуации, когда появляется полный набор коммуникантов с их интенциями, включая прежде всего адресата или адресатов, на которых и направлено текстовое сообщение, при этом в момент восприятия и понимания оно превращается в дискурс, поскольку «обрастает» социогенными обстоятельствами и прагматическим воздействием на адресата. Таким образом, текст функционирует как знак дискурса. Если заранее подготовить некий связный речевой континуум, характеризующийся завершенностью, логичностью, когезией и когерентностью, то возникнет текст, который еще не стал дискурсом, так как не вышел за рамки сознания его создателя, не стал элементом коммуникативной интеракции, потому что не приобрел пока адресата, ради которого и был задуман. Если читатель попадет в семиотическую ситуацию восприятия данного текста, то есть прочтет или прослушает текст про себя или вслух, то этот текст превратится в дискурс, поскольку процесс восприятия и понимания информации будет протекать в реальном времени и при участии адресата, в том числе и автоадресата, если коммуникативная интеракция ведется с самим собой, поскольку воспринятый текст 
может изменить самого говорящего и одновременно слушающего, то есть вызвать прагматический (перлокутивный) эффект.

Текст как знак дискурса может приобрести письменную форму, то есть долговременную форму существования. Это означает, что он в любой момент может вновь превратиться в дискурс, если возникнет адресат, который через много веков возьмет книгу в руки и прочтет древний текст, что породит эффект понимания информации, которая содержится в тексте. Следовательно, любой текст, включая древний, - это потенциальный дискурс. Текст может на долгое время «затаиться» и существовать в записанной форме, но как только некто обнаружит его и начнет читать, в результате в какой-то мере изменив свою картину мира под его воздействием, текст сразу превратится в дискурс на момент его чтения или слухового восприятия. Так происходит до бесконечности коммуникативных интеракций адресата и адресанта с участием данного текста.

Спецификой обладает устный текст (например, фольклорный или современный) в виде монолога или диалога, который воспринимается в процессе звуковой коммуникативной интеракции, - это «дискурс он-лайн». Если его не записать, он перестанет существовать как реальность после своего произнесения и переместится в виде фрагментов в память (иногда он запоминается слово в слово, то есть целиком, например, в эпосе или фольклоре). На протяжении многих тысячелетий человечество имело дело преимущественно с таким видом текста, однако возникновение письменности и книгопечатания, но особенно цифровой системы хранения и передачи информации и Интернета существенно изменило дискурсивное общение и породило тотальность коммуникативных интеракций.

\section{Интердискурс и интертекст}

Дискурс состоит из высказываний, которые представляет собой в минимальной совокупности и целостности не что иное, как речевые акты (далее - РА). Важно осознать высказывания и РА как составные элементы дискурса, если их рассматривать в плане семиозиса.
Означающим высказывания является реализованное предложение (локуция), означаемым оказывается иллокутивная семантика высказывания (пропозиция), которая формируется в сознании воспринимающего (адресата) при понимании и на основании которой адресат производит изменение в мире или себе самом, что образует перлокутивный эффект дискурсивной интеракции.

Важно отметить то обстоятельство, что в понимаемом смысле высказывания (то есть в пропозиции) информации больше, чем в поверхностной структуре предложения, поскольку в высказывании как единице дискурса актуализируются пресуппозиции - фоновые знания и жизненный опыт адресата. Таким образом, адресат в своем сознании суммирует высказанное и подразумеваемое в целостную смысловую конструкцию, являющуюся иллокуцией высказывания как элемента РА. Именно такое положение дел позволяет понимать предложение как знак высказывания. Подобным образом соотносятся текст и дискурс, то есть следует признать, что текст является знаком дискурса, состоящего из высказываний и речевых актов, при этом в дискурсе информации больше, чем в тексте, в силу активизации пресуппозиций дискурса - фоновых знаний адресата, которые способствуют пониманию (иногда неполному или ложному) дискурса в целом.

Денотатом высказывания как элемента дискурса можно признать перлокутивный эффект, то есть реальное изменение в миропонимании адресата либо изменение в положении дел в реальном мире, выгодное в той или иной степени инициатору дискурса, который и сформировал его в соответствии с конкретной интенцией. В этой связи в качестве основы для описания типов дискурса можно принять типологию речевых актов, разработанную Дж. Серлем, Дж. Остином и Дж. Россом, адаптированную для русского языка акад. Н.Д. Арутюновой.

Информация, которая находится в текстах прошлого, оказывает существенное влияние на дискурс в настоящем, что было открыто И. Кантом в его рассуждениях о времени. Можно сформулировать сильную онтологическую детерминанту, утверждая, что в дискурсе настоящего времени нет и не мо- 
жет быть информации, которая хотя бы в зачаточном виде не была заложена в дискурсе, зафиксированном в древних и старых текстах на основе событий прошедших времен. Говоря образно, в дискурсе настоящего прорастает зерно, брошенное в ткань дискурса в прошлом, это зерно родит злак, в котором есть и новое зерно, которое в свою очередь прорастет в будущем - и так до бесконечности.

В предыдущих наших работах мы назвали дискурсом бесконечную цепь сообщений в социальных контекстах на одну концептуальную тему от начала информационного взаимодействия в мире до настоящего времени (см., например: [Киров, 2009]). Целесообразно такую сумму дискурсивных произведений в виде текстов (записанных или запомненных), вставленных в социальные обстоятельства, изменяющие мир и людей при каждом факте восприятия (прочтения или прослушивания этих текстов, превращающихся в такой момент в дискурсы) назвать интердискурсом (об интердискурсе в другом понимании см.: [Чернявская, 2009]). В таком случае собственно дискурсом является отдельное конкретное речевое произведение в виде социализированной коммуникативной интеракции, объединенное когезией и когерентностью, аспектно развивающее одну концептуальную тему, которая «красной нитью» (И.В. Гете) проходит через интердискурс. Естественно, что возникает связь интертекстуальности и интердискурсивности, приводящая к выделению корреляции соотнесенных объектов - интертекста и интердискурса. Примером интертекста как своеобразного знака интердискурса будет вся совокупность текстов, например, о любви (к таким текстам относятся «Сказание о Петре и Февронии», «Евгений Онегин», «Анна Каренина», фольклорные сказания о любви и др.). Каждый из этих текстов в момент чтения или прослушивания превращается в дискурс и влияет на читателя, то есть обладает эффектом дискурсивной перлокуции.

\section{Разновидности дискурса и интердискурс}

Подробную типологию дискурсов предложил В.И. Карасик, выделив такие разновидности дискурсов, как институциональный (представительское общение), политический, административный, юридический, военный, педагогический, религиозный, мистический, медицинский, деловой, рекламный, спортивный, научный, сценический и массово-информационный [Карасик, 2000, с. 28].

М. Фуко в работе «Воля к жизни» выделяет бессубъектный дискурс, состоящий из бесконечно повторяющихся «монад языкового опыта» (по выражению Б.М. Гаспарова). М. Фуко пишет: «Можно предположить, что во всех обществах весьма регулярно существует разноуровневость дискурсов: есть дискурсы, которые “говорятся" и которыми обмениваются изо дня в день, дискурсы, которые исчезают вместе с тем актом, в котором они были высказаны; и есть дискурсы, которые лежат в основе некоторого числа новых актов речи, их подхватывающих, трансформирующих или о них говорящих, - словом, есть также дискурсы, которые - по ту сторону формулирования - бесконечно сказываются, являются уже сказанными и должны быть еще сказаны» [Фуко, 1994, с. 60]. В результате возникает круговорот и грандиозное, нескончаемое и необузданное, по выражению М. Фуко, бурление бессубъектного дискурса, которое, на наш взгляд, способствует формированию интердискурса.

Возвращаясь к вопросу о разновидностях дискурса, можно сказать, что их, на наш взгляд, столько, сколько в картине мира языкового сообщества выделено основных, базовых концептов (например, как в «Словаре русской культуры» Ю.С. Степанова), исторически формирующих тематическую цепь текстов и дискурсов на одну концептуальную тему [Киров, 2009]. Это первый и начальный этап в типологии дискурсов, на следующем этапе их можно объединять в функциональные поля, аналогичные типам дискурса, выявленным В.И. Карасиком, М. Фуко или О.Г. Ревзиной. Так, о бытовом дискурсе как функциональном поле дискурсов (неинституциональном, по терминологии В.И. Карасика) известно всем, однако он как полевое образование включает в себя разные тематические направления, или концептуальные цепи дискурсов, которые «красными нитями» сквозят через них и развивают одну и ту же тематику одного концепта. Такие дискурсивные цепи и поля характерны по преимуществу именно для бытовой 
жизни людей: они, например, развивают концептуальные темы: о пропитании, бытовых условиях, любви и ненависти и т. д. Поскольку мы плетем ткань такого дискурса повсеместно и ежечасно, общаясь между собой, то многие бытовые и спонтанные дискурсы исчезают после их произнесения, однако некоторые из них в частной истории одной семьи, в памяти членов этой семьи могут сохранятся в виде запомненных текстов. Если таким текстам «повезет», то они могут быть систематизированы в сознании великого писателя, в результате возникнут такие шедевры, как «Анна Каренина», «Евгений Онегин» и другие «тексты на все времена». Важно подчеркнуть, что в таких тексах имеется исторический фон в виде прецедентных фрагментов текстов и дискурсов, которые были произнесены или прочитаны в социальных обстоятельствах предшествующего времени.

Иллюстрации обыденного разговорного дискурса на литературном языке можно найти в книге Ю.М. Скребнева «Введение в коллоквиалистику» (1985), а также в издании, подготовленном коллективом авторов под руководством Е.А. Земской «Русская разговорная речь: Тексты» (1978), в работах представителей саратовской школы О.Б. Сиротининой (1983) и др. работах, посвященных описанию феномена русской разговорной речи.

Как особый вид дискурса необходимо рассматривать детский дискурс с его ограниченной концептуальной тематикой (онтодискурс), изучением детской речи занимается отдельная наука - онтолингвистика (см. работы С.Н. Цейтлин (2009) и ее учеников). Весьма специфичен арготический дискурс, который следует изучать особо, поскольку состав концептов и тематика реализующих их дискурсов также строго ограничена (см. работы М.А. Грачева (1997) и др.).

Естественно, что в непрерывной практике дискурсивных интеракций формируется и множество других цепей и полей интердискурса.

\section{Соотношение текстов и дискурсов}

Как уже говорилось выше, текст и дискурс не равны по объему передаваемой информации: в тексте ее меньше; часть инфор- мации в коммуникации уходит в подтекст, в пресуппозиции, фоновые знания, в имплицируемую часть дискурса (об этом см.: [Валгина, 2003]).

Из этого следует, что текст и дискурс соотносятся подобно многим языковым единицам и их речевым соответствиям. Так, звук и фонема соотносятся как реально звучащая единица речи и понимаемая, распознаваемая часть фонемного шифра слова [Киров, 1997, c. 414]. Подобным образом соотносятся слово как единица словаря языка и словоформасинтаксема в высказывании со своим значением и смыслом в пропозиции высказывания. Подобное соотношение наблюдается между предложением как единицей языка и высказыванием в коммуникативном плане. Текст и дискурс уместно поставить в этот ряд: текст и дискурс соотносятся подобно предложению и высказыванию с конкретизированным смыслом в рамках речевого акта. Смысл текста сам по себе релятивен и становится понятным только при преобразовании текста в дискурс в момент его восприятия и понимания адресатом, то есть реципиентом РА. Таким образом, дискурс можно определить как актуализированный в реальном времени текст с релятивно воспринятым и индивидуально понятым смыслом, который имеет перлокутивную направленность на адресата в соответствии с интенцией говорящего (пишущего). Таким образом, дискурс как вид деятельности никогда не производится без конкретной интенции, то есть он всегда ориентирован на индивидуального или коллективного адресата с целью достижения практических результатов в реальных жизненных условиях, выгодных адресанту дискурсивной интеракции. Другими словами, дискурс - это актуализированный в реальном времени текст или речевая импровизация в диалоге, которые имеют обязательное прагматическое задание в соответствии с интенцией участников дискурсивной интеракции. Характерной чертой дискурса является релятивно воспринятый смысл, который воздействует на адресата дискурсивной интеракции и на положение дел в мире в реальном времени.

Следуя семиотической теории как основе процесса коммуникации, приходится признать, что текст находится в тесном семиоти- 
ческом соотношении с дискурсом, являясь его знаком, и обязательно существует в определенной коммуникативной позиции - сильной, слабой или сверхслабой (о поняти сверхслабой позиции см.: [Киров, 1997, с. 255-262]).

Сильная текстово-дискурсивная позиция предполагает более или менее полное совпадение текста и дискурса. Предельным фактом совпадения текста и дискурса является перформативный дискурс и текст или их фрагменты (Например: Я объявляю заседание закрытым, все сотрудники свободны). Такая позиция для текста в коммуникативном пространстве может быть определена как сильная, и он оборачивается в конкретной обстановке его употребления релятивным аналогом дискурса, поскольку замысел говорящего эксплицитно выражен в форме текста и не может быть искаженно понят адресатами коммуникативной трансакции: согласно реальному положению дел сотрудники разойдутся, что и является конечной целью и интенцией председателя собрания. В таком случае между содержанием текста и дискурса имеется более или менее полное соответствие (текст - аналог, то есть знаккопия дискурса, подобно фотографии), то есть текст построен так, что его невозможно понять двояко, следовательно, это соотношение текста можно определить как аналоговое: дискурс с точки зрения воспринятого содержания становится семиотическим аналогом текста.

Однако наша коммуникативная практика отнюдь не всегда состоит из перформативных высказываний и речевых актов, образующих «перформотекст $\Rightarrow$ дискурс», поэтому в реальной коммуникации между текстом и дискурсом нередко возникают иконические, с одной стороны, или символические, с другой стороны, знаковые соответствия. Рассмотрим тот и другой случай по порядку.

Так, текст, в самом содержании которого имеется частичное соответствие со смыслом, который понимает адресат в процессе дискурсивной актуализации в конкретной социальной среде общения, становится иконическим знаком соответствующего дискурса, при этом в воспринимаемом и понимаемом смысле имеются элементы подтекстовой информации, возникающие из пресуп- позиций, интертекстуальных фоновых знаний, общих для членов коммуникативной интеракции, то есть имеющихся в сознании адресанта и адресата. Примером такого текста являются объявления, сообщения о продаже, законодательные акты, научные статьи и книги, рассказы о жизненных ситуациях, статьи в СМИ, реалистические художественные произведения и т. д. Они могут быть поняты достаточно индивидуально и не в том объеме, который предполагал автор текста, но всетаки более или менее однозначно всеми участниками дискурсивной интеракции. Таким образом, иконические тексты при дискурсивной актуализации в целом приводят к примерно одинаковым перлокутивным эффектам, поскольку смысл сообщений в таких случаях понимается примерно одинаково, именно поэтому с семиотической точки зрения их можно отнести к иконическим знакам соответствующего дискурса. В целом такой текст занимает слабую коммуникативную позицию, выполняя роль означающего, а соответствующий ему дискурс - слабую позицию означаемого в коммуникативной интеракции. При этом слабость такой текстоводискурсивной позиции обусловлена релятивной трактовкой понимаемого смысла сообщений в процессе дискурсивной интеракции.

В терминах теории речевых актов это соотношение можно описать следующим образом: если текст с содержанием, интенционально задуманным адресантом, выступает как локуция коммуникативной интеракции, то дискурс выступает как иллокутивный объект информационной интеракции. На основании релятивного восприятия смысла текста как иконического знака дискурса могут последовать неоднозначные выводы или реальные действия, что и будет представлять собой релятивную перлокутивную компоненту коммуникативной интеракции с участием текста и дискурса. Другими словами, если в сильной позиции перформативного текста и дискурса невозможно предположить неоднозначный перлокутивный эффект, то в слабой позиции иконического текста как знака соответствующего дискурса могут возникать индивидуально понятые смыслы или оттенки смыслов, что уже не приводит к однозначному перлокутивному эффекту (некоторые участни- 
ки дискурсивной интеракции могут понять смысл сообщений не до конца правильно и сделать что-то не так).

Рассмотрим третий случай семиотического соотношения текста и дискурса. В практике коммуникации мы встречаемся с текстами с трудно осознаваемым содержанием. Например, такими текстами являются стихотворные или символические произведения (типа романов Ф. Кафки, стихов «заумников» и русских символистов и т. д.). Эти тексты в своей внешне выраженной вербально-концептуальной структуре имеют мало соответствия с тем, что интенционально задумано автором как смысл текста, способного превратиться в дискурс. Тексты такого рода являются уже не иконическими знаками, как в предшествующем случае, а текстами-символами, то есть символическими знаками некоего дискурсивного содержания, которое обычно никто и никогда не дает в прямом пересказе и каждый понимает в значительной степени индивидуально. При восприятии символического текста как дискурса читатель распознает и понимает смысл аллегории или аллюзии исходя из собственного миропонимания, из идиоэтнической картины мира, из собственного багажа пресуппозиций и фоновых знаний. Нередко в такого вида текстах имеются «темные», непонятные фрагменты (или целые тексты в тексте, например, «Песнь песней» в Библии), и в этом случае требуются разъяснения: такой фрагмент или текст, как правило, научно комментируется герменевтом или текстологом. Тайный смысл символического текста, актуализированного как дискурс, неоднозначен как понимаемый объем информации «туманного» плана, то есть смысл, не высказанный прямо, но передаваемый намеками, аллюзиями и сложным символьным семиозисом, образует сложную «иллокутему», перлокутивная суть которой недостаточно явно выражена, но она есть, и от этого она не перестает быть собственно «перлокутемой» (возможно, и размытой). Однако социум не всегда правильно понимает смысл послания того или иного художника слова, переданного символическим текстом даже в виде «внешне обычного» текста, что может оказаться специальным художественным приемом. Так, традиционно считается, что в «Медном всаднике»
А.С. Пушкина описано петербуржское наводнение 1824 г., хотя, как мы показали в одной из наших работ, скорее всего, в поэме А.С. Пушкин осуществил давнюю мечту и дал символизированное описание декабристского восстания 1825 г. [Киров, 2011].

Таким образом, символические, религиозные, мифологические или абстракционистские и постмодернистские художественные тексты как символические знаки определенных информационных единств, сложившихся в сознании автора (адресанта коммуникативной интеракции), понимаются читателями (адресатами) достаточно индивидуально и не всегда так, как хотел бы автор текста. Но в любом случае символические тексты актуализируются в сверхслабой коммуникативной позиции, то есть превращаются в дискурс с очень размытым смыслом и соответствующим многовекторным перлокутивным эффектом, что в литературе как процессе описательной иллюстрации базовых концептов может быть вполне оправдано самим характером творчества, связанного с игрой фантазии посредством слова.

\section{Текст, дискурс и «стрела времени»}

Обратимся к такой важной, на наш взгляд особенности, относящейся к онтологии текста и дискурса, как их связь со «стрелой времени» («стрела времени» - это красивая философская метафора, ставшая термином).

Характер времени в тексте и дискурсе различен по своей сути, и это представляет серьезную лингвофилософскую проблему. Относительное текстовое время присутствует в самом тексте, о чем пишет Г.А. Золотова, разработавшая типологию внутритекстового времени. Как указывает Г.А. Золотова, в тексте может сообщаться о событиях в прошлом, будущем и настоящем в соответствии с модусами времени: «В объемном пространстве текстового времени могут взаимодействовать три темпоральных оси, или линии: Линия Т1 представляет календарное, природное, объективно бегущее время, внешнее по отношению к тексту, однонаправленное и необратимое $<$.. $>$ Линия Т2 реализует текстовое, событийное время (понятно, что речь идет о событиях, составляющих содер- 
жание данного текста); оно может в начале или в каких-то моментах развития быть проецировано на хронологическую ось, но это отнюдь не обязательное условие построения текста $<\ldots>$ Линия Т3 - это линия перцептивная, выражающая позицию говорящего (пишущего), реальную или мысленную, во времени и в пространстве по отношению к событиям текста» [Золотова, Онипенко, Сидорова, 1998, с. 22-23].

Совпадение времени говорения или письма и реального события наблюдается только при употреблении перформативных глаголов в соотвествующих перформативных текстах, являющихся знаками перформативных дискурсов. Если события, происходящие на наших глазах в настоящем, мы будем комментировать подобно футбольному матчу, нам придется использовать все глаголы как квазиперформативы (герой встает с кресла, направляется и т. д.), то есть в формах настоящего исторического времени, которые описывают действия, происходящее как бы на глазах очевидца. При этом сказанное будет формально совпадать с моментом реального времени, и в результате возникнет иллюзия, что мы поймали «стрелу реального времени» в момент производства высказывания. Однако в реально текущем времени мы сталкиваемся с такой ситуацией: на восприятие, распознавание и понимание произносимого говорящим квазиперформативного глагола слушающий тратит какое-то время, следовательно, «стрела времени» улетит до того, как акт коммуникации состоится. Здесь вполне уместно говорить о принципиальном несовпадении времени понимания и реального времени: в таком случае Ахиллес действительно никогда не догонит черепаху, и мы подобным рассуждением породим еще одну апорию: слушающий никогда не поймет говорящего, потому что, пока он понимает уже сказанное, говорящий добавляет к сказанному новые слова. Однако эта апория легко опровергается, если мы введем в рассуждение понятие семиозиca, в котором при помощи знаковой функции текста, то есть иконизации и символизации при актуализации текста, и превращения его в дискурс осуществляется компрессия информации в потоке коммуникативной интеракции. Иллюзия совпадения с реальным временем того времени, которое выражено в тексте, возникает потому, что в процессе коммуникации используются тексты как знаки, которые иконизируют или символизируют соответствующие им дискурсы по принципу монтажа (как в художественном фильме, по Эйзенштейну). Возникает непрерывный цикл воображаемых в сознании адресата скриптов событий, которые характеризуются нелинейностью: скрипты меняются местами, чередуются, следуют паралельно и т. д. Значимым условием восприятия такого цикла воображаемого является условное приравнивание времени текста к реальному времени: воспринимающее сознание воспринимает релятивное время текста как реальное время, тем самым актуализируя текст и превращая его в дискурс.

В этой связи будет уместным напомнить о разделении времени на онтологическое и физическое, проведенное А. Бергсоном в рамках философского осмысления этого феномена.

В науке представлено четыре концепции времени и пространства. Согласно субстанциональной модели время и пространство являются субстанциональными сущностями и не зависят от материальных объектов. В реляционной модели время и пространство определяют отношения порядка между объектами и процессами и не существуют независимо от них. В динамической модели принимается за существующее только настоящее время: на те события, что свершились или свершатся, повлиять невозможно, следовательно, иного времени, кроме настоящего, нет. В статической модели реально текущее время включается как часть во всеобее время (вечность), а реальное пространство - как часть во всеобщее пространство; при этом события в прошлом отражаются на событиях в настоящем и в будущем, поскольку они взаимосвязаны.

Мы считаем возможным синтезировать эти концепции и принимаем синтетическую, концепцию времени - пространства (эйнштейново понимание времени и пространства) с учетом однонаправленности движения времени из прошлого через настоящее в будущее (однонаправленности «стрелы времени»). Такое понимание времени позволяет относиться к нему релятивно, условно вос- 
принимать текстовое время как реальное время протекающих событий в дискурсе: читатель или зритель как бы проживает в реальном времени те события, которые существуют в текстовом времени при описании событий в нарративе.

Перспективной для анализа художественного дискурса является также концепция субъективно-психологического времени, разработанная С.А. Аскольдовым [Аскольдов, 1922]. Ее суть сводится к утверждению того, что время представляет собой другое имя изменения и имеет прошлое, настоящее и будущее только в том случае, если регистрируется сознанием. Данная концепция хорошо согласуется со сказанным выше, поскольку текстовое время условно воспринимается как физически текущее время только в воспринимающем текстовую информацию сознании.

В результате понимания и представления в сознании описываемых событий мы попадаем в иной мир с другим временем, которому приписываем статус реального времени (хотя это и условное соответствие). Когда мы читаем роман, к реальной жизни относится только сам факт чтения в данную минуту данного романа. То время, которое содержится внутри самого романа, не может быть равным реальному физическому времени, потому что художественное время - это виртуальное время в виртуальном мире. Таким образом, виртуальный мир художественного вымысла и реальный мир событий никогда не совпадают и существенно отличаются от физического времени, однако феномен восприятия содержания текста заключается в условном наблюдении воображаемых событий как реальных и приравнивании текстового и реального времени, то есть при восприятии и понимании текста мы условно полагаем, что то время, которое разворачивает цепь событий в тексте, как бы равно реальному, и на этой основе понимаем смысл текста, как бы превращая виртуальное время текста в реальное время дискурса.

Итак, мы приходим к утверждениям, что дискурс связан с реальным временем, если это перформативный речевой акт, или квазиреальным временем, условно понимаемым как реальное время в виртуальном мире текста, актуализированного как дискурс. Таким образом, дискурс - это и есть нарративно оформленная жизнь человека и языкового сообщества в реальных или вымышленных социальных обстоятельствах, то есть жизнь, протекающая не без помощи языковой коммуникации в том времени и социуме, которому мы приписываем статус реального. Жизнь человека и языкового сообщества имеет три измерения, или временных модуса: то, что происходит сейчас, в данную минуту, то, что уже произошло, то, что, вероятнее всего, произойдет, поскольку имеет начало в прошлом, длится сейчас и продлится в будущем. Однако то, что происходит сейчас, как уже говорилось, опирается на то, что было заложено в прошлом - это принципиальное положение философии И. Канта [Кант, 1999], ее непреложный закон временного детерминизма событий, который мы принимаем совершенно безоговорочно.

Дискурс, поскольку он вплетен в жизнь через свою перлокутивную компоненту и является ее частью, включен в социальные отношения и построен на основании своего специфического временного детерминизма, использует фактор времени как условно реальный. Чтобы быть понятым, дискурс не может не опираться на предшествующий опыт человека и человечества, так как пресуппозиции, необходимые для понимания смыслов высказываний дискурса, - это исторически складывающаяся сумма представлений, установок, мифов и реальных знаний, то есть сумма фоновых знаний, которые складываются исторически как в онто-, так и в филогенезе. Итак, дискурс - это произведение словесного типа, включенное в жизнь социума, которое имеет большой предшествующий исторический фон [Киров, 2009], формирующее в целом комплекс интердискурса одной концептуальной тематики. Более того, все говорящие или пишущие, то есть включенные в процесс дискурсивных практик, не могут создать ничего такого, чего бы не содержалось в зародыше или в виде потенциальной возможности в предшествующей «ткани» дискурса: сказать или написать можно только то, что уже как бы существует в потенции, что задано изначально траекторией построения дискурса (Р. Барт утрировал это положение в виде максимы о смерти автора). 


\section{Выводы}

Мегадискурс как коммуникативное богатство социума (дискурсивный тезаурус) существует и развивается с начала коммуникативной деятельности общества до настоящего времени. Структурно дискурс как часть мегадискурса посвящен развитию одной концептуальной темы, отличается связностью и цельностью и имеет характер относительно законченного речевого произведения. Человек, постоянно обогащаясь информацией, получая образование, знакомится с дискурсивной культурой социума и включается в «бурление» коммуникативно-дискурсивных интеракций, как говорил М. Фуко. Он не может выйти за рамки национальной дискурсивной культуры, не освоив новый для себя язык и новую дискурсивную культуру как сумму мегадискурсов, описывающих «концептуалитет» социума. Другими словами, выйти за рамки национального дискурса мы можем лишь в том случае, если перейдем в другой национальный дискурс, формирующийся при помощи другого национального языка и образующий другую национальную дискурсивную культуру (впрочем, ничто не мешает человеку входить в несколько дискурсивных культур, если он владеет несколькими языками). В этом смысле и следует понимать известное положение В. фон Гумбольдта о том, что язык создает вокруг человека круг, за рамки которого невозможно выйти, если не перейти в круг другого языка. Ткань дискурса сплетена к настоящему моменту настолько, насколько это удалось языковому сообществу, однако это не значит, что плетение дискурсивной ткани завершено. Дискурс имеет огромную предысторию и потенциальную проекцию, которая объективна как реальность будущего дискурса. В таком контексте можно понять и самую загадочную в теории языка фразу И. Лео Вайсгербера о том, что «язык думает за нас» [Вайсгербер, 1993].

Итак, при всей своей близости текст и дискурс - не одно и то же. Текст - это оформленный по законам жанра аналогический, иконический или символический знак дискурса либо его бесформенный фрагмент, если это спонтанный разговорный или постмодернистский литературный текст, не имеющий формального начала или конца.

\section{СПИСОК ЛИТЕРАТУРЫ}

Арутюнова Н. Д., 1990. Дискурс // Лингвистический энциклопедический словарь. М. : Советская энциклопедия. С. 136-137.

Аскольдов С. А., 1922. Время и его преодоление // Мысль. № 3. С. 80-83.

Вайсгербер Й. Л., 1993. Родной язык и формирование духа. Ульяновск : Изд-во МГУ им. М.В. Ломоносова (филиал в Ульяновске). 232 с.

Валгина Н. С., 2003. Теория текста. М. : Логос. 280 с.

Грачев М. А., 1997. Русское арго. Нижний Новгород : НГЛУ. $245 \mathrm{c}$.

Земская Ю. Н. и др., 2010. Теория текста. М. : Флинта. $132 \mathrm{c}$.

Золотова Г. А., Онипенко Н. К., Сидорова М. Ю., 1998. Коммуникативная грамматика русского языка. М. : Изд-во МГУ. 528 с.

Кант И., 1999. Критика чистого разума. Ростов н/Д : Феникс. 464 с.

Карасик В. И., 2000. Структура институционального дискурса // Проблемы речевой коммуникации : сб. науч. тр. Саратов : Изд-во Сарат. ун-та. С. 25-33.

Киров Е. Ф., 1997. Фонология языка. Ульяновск : Издательство СВНЦ. $451 \mathrm{c.}$

Киров Е. Ф., 2009. Начала концептуально-дискурсивной лингвистики // Система языка и языковое мышление / отв. ред. Е. Ф. Киров. М. : ЛИБРОКОМ. С. 66-96.

Киров Е. Ф., 2011. Потаенные смыслы «Медного всадника» А.С. Пушкина // Inveniens quaero. Vilnius : LEU. C. 386-403.

Макаров М. Л., 2003. Основы теории дискурса. М. : Гнозис. 277 с.

Ревзина О. Г., 1999. Язык и дискурс // Вестник Московского университета. Серия 9. Филология. № 1. C. $25-34$.

Русская разговорная речь: тексты, 1978. Отв. ред. Е. А. Земская и Л. А. Капанадзе. М. : Наука. $485 \mathrm{c}$.

Серио П., 1999. Как читают тексты во Франции // Квадратура смысла. Французская школа анализа дискурса. М. : Прогресс. С. 12-53.

Сиротинина О. Б., 1983. Русская разговорная речь. М. : Просвещение. $80 \mathrm{c}$.

Скребнев Ю. М., 1985. Введение в коллоквиалистику. Саратов : Изд-во Сарат. ун-та. 209 с.

Фуко М., 1994. Слова и вещи. Археология гуманитарных наук. СПб. : A-cad. 408 c.

Цейтлин С. Н., 2009. Очерки по словообразованию и формообразованию в детской речи. М. : Знак. 592 c.

Чернявская В. Е., 2009. Лингвистика текста: поликодовость, интертекстуальность, интердискурсивность. М. : Либроком. 248 с. 


\section{RERERENCES}

Arutyunova N.D., 1990. Discourse. Linguistic Encyclopedic Dictionary. Moscow, Sovetskaya entsiklopediya Publ., pp. 136-137.

Askoldov S.A., 1922. Time and overcoming it. Mysl, no. 3 , pp. 80-83.

Weissgerber J.L., 1993. Native language and spirit development. Ulyanovsk, Izd-vo MGU im M.V. Lomonosova (filial v Ulyanovske). 232 p.

Valgina N.S., 2003. The theory of text. Moscow, Logos Publ. 280 p.

Grachev M.A., 1997. Russian Argo: monograph. Nizhny Novgorod, NGLU Publ. 245 p.

Zemskaya Yu.N., et al., 2010. The theory of text: textbook. Moscow, Flinta Publ. 132 p.

Zolotova G.A., Onipenko N.K., Sidorova M.Yu., 1998. Communicative grammar of the Russian language. Moscow, Izd-vo MGU. 528 p.

Kant I., 1999. Critique of pure reason. Rostov-on-Don, Feniks Publ. 464 p.

Karasik V.I., 2000. The structure of institutional discourse. Problemy rechevoy kommunikatsii. Saratov, Izd-vo SGU, pp. 25-33.

Kirov E.F., 1997. Language phonology. Ulyanovsk, Izd-vo SVNTs. $451 \mathrm{p}$.

Kirov E.F., 2009. The beginning of conceptual and discursive linguistics. Sistema yazyka $i$ yazykovoe myshlenie. Moscow, LIBROKOM Publ., pp. 66-96.
Kirov E.F., 2011. Hidden meanings of The Copper Horseman by Alexander Pushkin. Inveniens quaero. Vilnius, LEU, pp. 386-403.

Makarov M.L., 2003. Fundamentals of the theory of discourse. Moscow, Gnozis Publ. 277 p.

Revzina O.G., 1999. Language and discourse. Vestnik Moskovskogo universiteta. Seriya 9. Filologiya [Moscow State University Bulletin. Series 9. Philology], no. 1, pp. 25-34.

Zemskaya E.A., Kapanadze L.A. (eds.), 1978. Russian spoken discourse: Texts. Moscow, Nauka Publ. $485 \mathrm{p}$.

Serio P., 1999. The reading of texts in France. Kvadratura smysla. Frantsuzskaya shkola analiza diskursa. Moscow, Progress Publ., pp. 12-53.

Sirotinina O.B., 1983. Russian conversational speech: a teacher's guide. Moscow, Prosveshchenie Publ. 80 p.

Skrebnev Yu.M., 1985. Introduction to colloquialism studies. Saratov, Izd-vo SGU. 209 p.

Foucault M., 1994. Words and things. The archeology of the humanities. Saint Petersburg, A-cad Publ. $408 \mathrm{p}$.

Tseitlin S.N., 2009. Essays on word formation and pattern formation in children's speech. Moscow, Znak Publ. 592 p.

Chernyavskaya V.E., 2009. Text linguistics: polycode nature, intertextuality, interdiscursivity. Moscow, Librokom Publ. 248 p.

\section{Information about the Author}

Evgeniy F. Kirov, Doctor of Sciences (Philology), Professor, Department of General and Russian Linguistics, Pushkin State Russian Language Institute, Akademika Volgina St., 6, 117485 Moscow, Russia, evg-kirov@yandex.ru, https://orcid.org/0000-0002-9836-5619

\section{Информация об авторе}

Евгений Флорентович Киров, доктор филологических наук, профессор кафедры общего и русского языкознания, Государственный институт русского языка им. А.С. Пушкина, ул. Академика Волгина, 6, 117485 г. Москва, Россия, evg-kirov@yandex.ru, https://orcid.org/0000-0002-9836-5619 